\title{
European Union copyright law and the Charter of Fundamental Rights-Advocate General Szpunar's Opinions in (C-469/17) Funke Medien, (C-476/17) Pelham GmbH and (C-516/17) Spiegel Online
}

\author{
Jonathan Griffiths ${ }^{1}$ \\ Published online: 8 May 2019 \\ (C) The Author(s) 2019
}

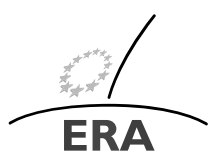

EUROPÄISCHE RECHTSAKADEMIE ACADEMY OF EUROPEAN LAW ACADEMIE DE DROIT EUROPEEN ACCADEMIA DI DIRITTO EUROPEO TRIER - TREVES - TREVIRI

\begin{abstract}
Increasingly, national courts have begun to consider the impact of the Charter of Fundamental Rights on EU copyright law. In (C-469/17) Funke Medien, (C-476/17) Pelham GmbH and (C-516/17) Spiegel Online v Volker Beck, the German Federal Supreme Court has referred a series of important questions about the relationship between the Charter, copyright law and national constitutional norms. This article explores the Opinions of Advocate General Szpunar in those cases and considers some of the broader potential consequences of the approach that he advocates.
\end{abstract}

Keywords Copyright law $\cdot$ Charter $\cdot$ Funke Medien $\cdot$ Spiegel Online $\cdot$ Pelham

\section{Introduction-copyright law \& the charter}

European Union copyright law must be interpreted and applied in a manner that ensures the protection of the fundamental rights of those affected by its rules. It is therefore not surprising that the Union's legislature, the Court of Justice and national courts have increasingly begun to consider the impact of the Charter of Fundamen-

J. Griffiths

j.griffiths@qmul.ac.uk

1 Professor of Intellectual Property Law, School of Law, Queen Mary, University of London, London, UK 
tal Rights in this sphere. ${ }^{1}$ Reference to the Charter has brought certain advantages. ${ }^{2}$ In (C-201/13) Deckmyn v Vandersteen, for example, the concept of a "fair balance" between competing rights facilitated the development of workable rules in an incomplete area of the acquis. ${ }^{3}$ While Article 5(3)(k) of the Information Society Directive ("the Directive") permits member states to implement an exception for "caricature, parody or pastiche", it does not provide the necessary boundaries for the appropriate functioning of the exception. Through the combination of an expansive definition of the concept of parody with an obligation upon member state courts to secure a "fair balance" between the competing rights of those affected, the Court succeeded in creating an interpretative framework within which a more detailed harmonised approach to the parodic use of copyright works can be developed over time.

However, the Charter also presents challenges. It has been suggested that reference to "external" constitutional constraints disturbs the stability of established rules and arrangements in copyright law. From this perspective, fundamental rights serve as a potential threat both to the high level of legal protection accorded to authors and other right-holders and to the maintenance of an increasingly harmonised system. 4 The Court's reliance on the Charter in its copyright jurisprudence has also been criticised from a very different angle, by those who suggest that the employment of a fundamental rights framework in copyright law will inevitably, and unjustifiably, reinforce right-holders' economic position in the face of competing policy interests. This danger has been identified, particularly, in the application of Article 17(2) of the Charter, under which a person's peaceful enjoyment of intellectual property (including copyright and related rights) has entrenched status. ${ }^{5}$

The reference to "fair balance" in Deckmyn, and other Judgments of the Court, ${ }^{6}$ also disguises continuing uncertainty about significant aspects of the system of rights protection applicable in this context. ${ }^{7}$ What, for example, is the relationship between the apparently inviolable "essence" of each of the rights protected under the Charter 8

\footnotetext{
${ }^{1}$ See, for example, (C-275/06) Promusicae v Telefónica de España EU:C:2008:54; (C-70/10) Scarlet Extended v SABAM EU:C:2011:771; (C-314/12) UPC Telekabel v Constantin Film Verleih GmbH EU:C:2014:192; (C-145/10) Eva-Maria Painer v StandardVerlags GmbH EU:C:2013:138; (C-510/10) DR, TV2 Danmark AS v NCB -Nordisk Copyright Bureau EU:C:2012:244; (C-201/13) Deckmyn v Vandersteen EU:C:2014:2132; (C-160/15) GS Media BV v Sanoma Media Netherlands BV EU:C:2016:644; (C-149/17) Bastei Lubbe GmbH \& Co KG v Strotzer EU:C:2018:841.

${ }^{2}$ And has been welcomed by some commentators. See, for example, P. Oliver \& C. Stothers [12]; C. Geiger [5].

${ }^{3}$ See J. Griffiths [7].

${ }^{4}$ See A. Lucas \& J. Ginsburg [1].

${ }^{5}$ See T. Mylly [13], 127 et seq; M. Husovec [11].

${ }^{6}$ See, for example, (C-275/06) Promusicae v Telefónica de España EU:C:2008:54 [68]-[70]; (C-70/10) Scarlet Extended v SABAM EU:C:2011:771 [49]; (C-314/12) UPC Telekabel v Constantin Film Verleih GmbH EU:C:2014:192 [46]-[47]; (C-484/14) McFadden v Sony Music Entertainment Germany GmbH EU:C:2016:689 [83]-[89] (C-149/17) Bastei Lubbe GmbH \& Co KG v Strotzer EU:C:2018:841 [45]-[47].

${ }^{7}$ See D. Jongsma [6], or http://dx.doi.org/10.2139/ssrn.3328100.

${ }^{8}$ Art 52, Charter of Fundamental Rights of the European Union:
}

"Any limitation on the exercise of the rights and freedoms recognised by this Charter must be provided for by law and respect the essence of those rights and freedoms. Subject to the principle of 
and the need to secure a fair balance — or proportionality ${ }^{9}$ How are other, equally fundamental interests arising under the Treaty (the freedom of movement of goods and the freedom to compete, for example) to be accommodated within, or alongside, a structure drawn from the Charter? How is the need to secure a "fair balance" between competing rights in the interpretation and application of copyright exceptions and limitations to be reconciled with the principle of "narrow interpretation"10 or the "three-step test". Over time, clearer answers to these questions will very probably emerge. However, current uncertainty has been compounded by the inconsistency of the Court's references to fundamental rights in its copyright jurisprudence. In some instances, the rights protected under the Charter have assumed key significance. ${ }^{11}$ In others, however, they have not been mentioned, even in circumstances in which they might have appeared to be relevant. ${ }^{12}$

In this situation, national courts will undoubtedly have questions about the role played by fundamental rights in the Union's copyright law. Jurisdictions with a previously-established legal tradition of reference to constitutional values in copyright proceedings might be expected to accommodate the Court's constitutional turn most easily. However, they must also reconcile established domestic constitutional norms with the requirements of the Charter. This is the situation in which the German Supreme Court (BGH) has found itself in three recent copyright cases. It is therefore not surprising that the $\mathrm{BGH}$ has chosen to make a co-ordinated series of references to the Court in (C-469/17) Funke Medien NRW GmbH v FRG ("Funke Medien"); 13 (C-476/17) Pelham GmbH v Hütter ("Pelham"); ${ }^{14}$ and (C-516/17) Spiegel Online v Volker Beck ("Spiegel Online"). ${ }^{15}$ These references present an important opportunity for the Court to clarify the relationship between copyright law and the rights protected under the Charter. The Opinions of Advocate General Szpunar in all three cases are now available, having been handed down between October 2018 and January 2019. In sections B to D below, the Opinions in Funke Medien, Pelham and Spiegel Online are explored turn. Section E briefly considers some of the broader potential consequences of the approach that the Advocate General traces in these Opinions.

proportionality, limitations may be made only if they are necessary and genuinely meet objectives of general interest recognised by the Union or the need to protect the rights and freedoms of others."

\footnotetext{
${ }^{9}$ For discussion, see $R$ (on the application of British American Tobacco (UK) Limited) $v$ The Secretary of State for Health [2016] EWHC 1169 (Admin) [825]-[843]; [2016] EWCA Civ 1182 [116]-[124].

${ }^{10}$ See, for example, (C-5/08) Infopaq International v Danske Dagblades Forening EU:C:2009:465 [56]; (C-435/12) ACI Adam BVv Stichting de Thuiskopie EU:C:2014:25 [22]). For a suggestion that the principle of strict interpretation may have to give way in cases in which an exception is designed to secure the interest in freedom of expression, see A. Lucas \& J. Ginsburg [1], 78.

${ }^{11}$ See, for example, (C-275/06) Promusicae v Telefónica de España EU:C:2008:54; (C-277/10) Luksan v Van der Let EU:C:2012:65; (C-201/13) Deckmyn v Vandersteen EU:C:2014:2132; (C-160/15) GS Media BV v Sanoma Media Netherlands BV EU:C:2016:644.

${ }^{12}$ See, for (C-301/15) Soulier \& Doke EU:C:2016:878.

${ }^{13}$ EU:C:2018:870, 25th October 2018.

${ }^{14}$ EU:C:2018:1002, 12th December 2018.

${ }^{15}$ EU:C:2019:16, 10th January 2019.
} 


\section{Funke Medien ${ }^{16}$}

In the national proceedings in Funke Medien (sometimes called the "Afghanistan Papers" case), the German Federal government claimed copyright in confidential documents describing overseas troop deployments. These documents were obtained and published by Funke Medien ("the defendant"). The government brought proceedings for copyright infringement and the BGH referred a series of questions to the Court, asking (i) about the degree of latitude available to national courts in interpreting the rights and exceptions established under national legislation implementing the Information Society Directive ("the latitude question"); (ii) about the way in which fundamental rights under the Charter were to be taken into account in ascertaining the scope of rights and limitations in the copyright acquis ("the broad Charter question"); and (iii) whether the rights of freedom of information and/or freedom of the media could justify exceptions or limitations beyond those provided for in Art 5 of the Directive ("the Charter exceptions question").

In his Opinion, the Advocate General doubts the admissibility of the reference, on the basis that the existence of copyright in the "purely informative" documents at issue is dubious and has not been verified by the national court. ${ }^{17}$ Nevertheless, he also considers the substantive questions raised by the BGH. These are not approached in the generalised terms formulated by the national court. Rather, Advocate General Szpunar takes a more particularised approach to the dispute, under which the proportionality of any potential interference with the defendant's freedom of expression is assessed within a framework derived from the Charter. In his view, there is an inherent conflict between copyright and freedom of expression but that this is generally resolved through the application of the ideas/expression dichotomy or through the exceptions and limitations. However, he acknowledges that there may be "exceptional cases where copyright ... must yield to an overriding interest relating to the implementation of a fundamental right or freedom." 18

Adopting the analytical structure established under the European Convention on Human Rights, ${ }^{19}$ the Advocate General notes that reliance on copyright by the Federal government in this instance constitutes a prima facie restriction on freedom of expression and must therefore be justified under Art 10(2), ECHR. The most obvious justification in this instance would appear to be the protection of national security. ${ }^{20}$ However, the Federal government had chosen not to pursue a national security-based cause of action, but to rely on copyright instead. On this basis, it is necessary to ask whether the interference can be justified as a limitation designed to secure the

\footnotetext{
${ }^{16}$ For analysis, see C. Geiger \& E. Izyumenko [3].

${ }^{17}$ EU:C:2018:870 [14]-[22].

${ }^{18}$ Ibid. [40]. Noting the significance of this development, see C. Geiger \& E. Izyumenko [3]. This principle is also implicit in the Judgments of the European Court of Human Rights in Ashby Donald v France 36769/08, 10th January 2013 and Neij \& Sunde Kolmisoppi v Sweden [2013] ECDR 7. For discussion, see C. Geiger \& E. Izyumenko, "Copyright on the Human Rights Trial" (2014) 45 IIC 316.

${ }^{19}$ Ibid. [41]-[43].

${ }^{20}$ Ibid. [47]-[49].
} 
"rights of others". However, states do not enjoy fundamental rights, which function to "protect individuals against the State, not the State against individuals". ${ }^{21}$ In such circumstances, according to the Advocate General, the only potentially legitimate reason for interfering with the defendant's freedom of expression (under Art 10(2), ECHR) could be the "public interest". However, in this instance, the German government had acknowledged that a prosecution for disclosure of the documents in this case would be disproportionate and, as such, it could not invoke its copyright interest in the public interest.

Even if the state's copyright interest were potentially capable of justifying the interference with freedom of expression here, such interference would have to be proportionate. In order to assess proportionality in such a situation, it is necessary to understand the objectives of copyright law. The Advocate General explains the two objectives of copyright law as the protection of the personal relationship between author and work and the facilitation of the economic exploitation of works. Neither objective would be served by the bringing of copyright proceedings in this instance because (i) there is no real human author of the reports at issue nor (ii) the government is not concerned with the economic exploitation of those documents. ${ }^{22}$ In the view of the Advocate General, the existence of a cause of action for copyright infringement in such circumstances would constitute a damaging exercise of state censorship. ${ }^{23}$ Accordingly, he advises that Article 11 of the Charter, read in conjunction with Article 52(1), precludes a Member State from invoking copyright in circumstances such as those at issue here.

Having concluded thus, the Advocate General returns to the questions referred. He thinks that it is unnecessary for the Court to respond to the latitude question because, in this instance, the proceedings can be resolved through the direct application of the Charter to the acquis. ${ }^{24}$ On the broad Charter question, he distinguishes Deckmyn. That case concerned the interpretation of a copyright exception whereas, here, the very existence of copyright protection cannot be established. On the Charter exceptions question, the Advocate General again emphasises the fact-specific nature of his analysis:

It is one thing to give precedence to freedom of expression over copyright in a specific and very particular situation. It is quite another to introduce into the harmonised copyright system, outside the provisions of substantive EU law governing that area, exceptions and limitations which, by their nature, are intended to apply generally. ${ }^{25}$

\footnotetext{
${ }^{21}$ Ibid. [53].

${ }^{22}$ Ibid. [58]-[61].

${ }^{23}$ Ibid. [64].

${ }^{24}$ Ibid. [68].

${ }^{25}$ Ibid. [71].
} 


\section{Pelham}

The national proceedings in Pelham arose as a result of the sampling of a recognisable two-second extract from a protected sound recording ${ }^{26}$ (Kraftwerk's Metall auf Metall) in a subsequent sound recording (Nur mir, featuring singer, Sabrina Setlur). The resulting dispute has occupied the national courts, including the German Constitutional Court, for several years. ${ }^{27}$ The BGH referred a number of questions, asking (i) whether the reproduction of very short extracts from a sound recording infringes the producer's reproduction right under Art 2 of the Directive; (ii) whether a sound recording containing very short audio snatches from an earlier recording is a copy of that earlier recording within the meaning of Art 9(1)(b), Directive 2006/115 ${ }^{28}$; (iii) whether the free use doctrine under Art 24(1) of the German Copyright Act is compatible with EU copyright law; (iv) whether the use of an extract from a work or other subject matter in circumstances in which it is not evident that another person's work or other subject matter is being used can fall within the quotation exception under Art 5(3)(d) of the Directive. In addition, as in Funke Medien, the BGH referred the latitude question, and the general Charter question.

In responding to the first of these questions, Advocate General Szpunar considers that "it goes without saying" 29 that the sampling of a small extract from a sound recording without permission infringes the reproduction right in that recording. The defendants, and several intervening parties, claimed that the reproduction of such a small extract of a sound recording ought not to be considered to be an infringement. They advanced a number of arguments in support of this position, including suggestions (i) that a de minimis principle ought to be applied by analogy with the approach taken to authorial works; (ii) that sound recordings should not be more strongly protected than such works; (iii) that the legal protection available for databases, which incorporates a threshold, is analogous to that available for sound recordings and (iv) that the concept of reproduction applies only to the reproduction of whole sound recordings as a matter of international copyright law. However, the Advocate General is not convinced by any of these arguments. ${ }^{30}$ To his mind, serious practical difficulties, uncertainty and divergence between national regimes would arise if such a threshold were to be applied and, accordingly, he advises the Court to decide that the reproduction of any extract from a sound recording in the course of sampling infringes the producer's reproduction right.

On the second question, the Advocate General advises that the meaning of "copy" for the purpose of the distribution right under Art 9(1)(b) of Directive 2006/115 is

\footnotetext{
26 "Sound recordings" are described as "phonograms" in the legislative acquis. See, for example, Directive 2001/29 of the European Parliament and of the Council of 22 May 2001 on the harmonisation of certain aspects of copyright and related rights in the information society, Art 2(c).

${ }^{27}$ For discussion of the domestic proceedings, see B.J. Jütte \& H. Maier [2].

${ }^{28}$ Directive 2006/115 of the European parliament and of the Council of 12 December 2006 on rental right and lending right and on certain rights related to copyright in the field of intellectual property (codified version).

${ }^{29} \mathrm{EU}: \mathrm{C}: 2018: 1002$ [26].

${ }^{30}$ Cf., L. Bently et al. [10], [3.1]-[3.9].
} 
narrower than that applicable under the Directive. Drawing on the Geneva Phonograms Convention, which is targeted at piracy, he concludes that, in the context of Directive 2006/115, a "copy" is a copy which incorporates all or a substantial part of the sounds of a protected phonogram and which are intended to replace lawful copies thereof. ${ }^{31}$

In considering whether the "free use" doctrine under Art 24(1) of the German Copyright Act is compatible with the Union's legislative acquis, the Advocate General notes that Member States are not permitted to provide for national exceptions that extend beyond the scope of those listed in Art 5 of the Directive. In this regard, it makes no difference that the "free use" principle is regarded as an inherent limitation on the exclusive rights of rightholders, rather than as an exception, in national law. If Member State were free to introduce such limitations outside Art 5, the effectiveness of the harmonisation of Union copyright law would be threatened. ${ }^{32}$

On quotation, the Advocate General notes that the exception may apply to musical works and sound recordings, as well as to literary works, ${ }^{33}$ but is subject to a number of constraints. Art 5(3)(d) covers quotation "for purposes such as criticism or review", which indicates that any quotation within the provision must enter into "some kind of dialogue with the work quoted". 34 The quoted material must also be distinguishable from the work in which it is quoted and must not be altered. ${ }^{35}$ The requirement that the quoted material should be distinguishable is to be inferred from the need for a dialogue between quoting work and work quoted. Without demarcation, such dialogue would not be possible. ${ }^{36}$ Sampling, such as that at issue in the national proceedings, cannot satisfy these conditions:

The aim of sampling is not to enter into dialogue with, be used for comparative purposes, or pay tribute to the works used. Sampling is the act of taking extracts from other phonograms, which are used as raw materials, to be included in new works to form integral and unrecognisable parts. Moreover, those extracts are often modified and mixed in such a way that all original integrity is lost. It is not therefore a form of interaction but rather a form of appropriation. ${ }^{37}$

Furthermore, as the Advocate General notes, Art 5(3)(d) explicitly requires the source of a quoted work, or other subject-matter, to be indicated unless it is not possible to do so. ${ }^{38}$ In the case of musical works, such indication of source may be difficult but could be achieved through, for example, a description or a title. ${ }^{39}$ In this instance, there was no indication of source.

\footnotetext{
${ }^{31}$ EU:C:2018:1002 [41]-[49].

${ }^{32}$ Ibid. [50]-[59].

${ }^{33}$ Ibid. [62].

${ }^{34}$ Ibid. [64].

${ }^{35}$ Ibid. [65]. Some amendments are traditionally accepted (translation, for example).

${ }^{36}$ Cf. L. Bently et al. [10], [4.7].

${ }^{37}$ Ibid. [67].

${ }^{38}$ Art 5(3)(d) permits "quotations for purposes such as criticism or review, provided that they relate to a work or other subject-matter which has already been lawfully made available to the public, that, unless this turns out to be impossible, the source, including the author's name, is indicated, and that their use is in accordance with fair practice, and to the extent required by the specific purpose." [Italics added].

${ }^{39}$ EU:C:2018:1002 [68].
} 
On the latitude question, the Advocate General notes that, in implementing EU law, national authorities and courts remain free to apply national fundamental rights standards, as long as they do not compromise the "primacy, unity and effectiveness" of EU law. ${ }^{40}$ The rights provided for authors and other right holders under the Directive are unconditional and mandatory and the list of exceptions under Art 5 is exhaustive. Member States cannot rely on national constitutional provisions to avoid implementation of these obligations. They may choose the form and methods of implementation and, in that choice, may be guided by national constitutional provisions, so long as the effectiveness of EU law is not undermined. ${ }^{41}$

As in Funke Medien, the Advocate General is reluctant to address the broad Charter question in general terms. Accordingly, he reformulates as an enquiry whether the freedom of the arts under Art 13 of the Charter takes priority over the exclusive right of reproduction enjoyed by producers of sound recordings. Employing a similar framework of analysis to that applied in Funke Medien, he acknowledges the inherent conflict between copyright and related rights, on the one hand, and freedom of expression and freedom of the arts, on the other. Given the existence of this conflict, there is a need to strike a balance between competing rights. In the first instance, the task of striking this balance between competing rights is the legislature's responsibility and is achieved through the framing of statutory exceptions and limitations. ${ }^{42}$ The legislature enjoys a broad margin of appreciation. Save in "exceptional cases", any judicial balancing of rights must be conducted within the limits of the legislative provisions. The European legislator has acknowledged the freedom of the arts in providing exceptions and limitations for, in particular, quotation and caricature, parody and pastiche. ${ }^{43}$ The Advocate General does not consider that the Charter's freedom of creativity requires the recognition of a broader exception for creative re-use. ${ }^{44}$ In future, the EU legislature may decide to introduce an exception for sampling. However, in exercising its function of judicial review, the Court should only depart from the text of the governing provisions in cases in which a "gross violation of the essence of a fundamental right" would otherwise arise. This was not such a case. ${ }^{45}$

\section{Spiegel Online}

Volker Beck is a German politician. In 1988, a controversial essay was published under his name. Subsequently, he sought to distance himself from the views expressed in the essay, claiming that the editor of the collection in which the essay had appeared

\footnotetext{
${ }^{40}$ Ibid. [73]. C-399/11 Melloni EU:C:2013:107.

${ }^{41}$ Ibid. [75]-[79]. There appears to be a potential inconsistency between this position and previous statements of the Court, in which it has been suggested that Member States are not free to determine the limits of the exceptions and limitations when transposing options listed in Art 5. See, for example (C-435/12) ACI Adam BV v Stichting de Thuiskopie EU:C:2014:25 [49]; (C-510/10) DR, TV2 v NCB Danmark A/S EU:C:2012:244 [36]; (C-201/13) Deckmyn v Vandersteen EU:C:2014:2132 [16].

${ }^{42}$ Ibid. [94].

${ }^{43}$ Ibid [95].

${ }^{44}$ Ibid. [96].

${ }^{45}$ Ibid. [98].
} 
had made amendments without his approval. In 2013, he made two versions of his essay available on his website (the original manuscript version and the version as published) alongside text setting out his view that the text of the published version had been changed by the editor without his consent. Spiegel Online published an article claiming that, contrary to Beck's position, the editor had not made significant changes to the material content of the essay. Alongside the article, both versions of the essay were made available for download via a hypertext link. Beck sued for copyright infringement and the $\mathrm{BGH}$ referred a series of questions about the interpretation of the exceptions and limitations under Art 5 to the Court of Justice. These include the latitude question, the broad Charter question and the Charter exceptions question. In addition, the BGH referred specific questions concerning the exception for reporting current events under Art 5(3)(c) and the quotation exception under Art 5(3)(d).

On the latitude question, noting his Opinion in Pelham, Advocate General Szpunar reiterates the limited nature of such freedom and rejects Spiegel Online's argument that Member States enjoy a broad margin of appreciation because these proceedings fall within the sphere of "culture". ${ }^{46}$ In his view, such an approach would frustrate the Union's ability to harmonise rules over a wide area of activity. Before tackling the questions relating to the relationship between the Charter and the law of copyright and related rights, which are left to the end of his Opinion, the Advocate General considers the questions referred on the interpretation of particular exceptions under the Directive. ${ }^{47}$

The $\mathrm{BGH}$ asked whether the reporting current events exception ${ }^{48}$ could be limited to situations in which it would be unreasonable to expect a user to seek permission to use a protected work. The Advocate General advises that such a restriction is not only permissible, but is actually an inherent requirement of the exception, which only applies "to the extent justified by the informatory purpose" of a use. ${ }^{49}$ In any event, in the view of the Advocate General, the exception could not apply on the facts of this case because Spiegel Online's use of the work was not simply in connection with a report of current events, but was rather intended to demonstrate that the two versions of the article were identical in essence. In order for such a purpose to be achieved, a reader of the defendant's article had to read the essay in its two forms. Interpreted in the light of Art 10(2) of the Berne Convention, Art 5(3)(c) does not cover the use of a literary work within the setting of a news report when the reading of the whole or a part of the work is intended to take place as a consequence of such use. ${ }^{50}$

\footnotetext{
${ }^{46}$ As a consequence of TFEU, Art 167(4).

${ }^{47} \mathrm{EU}: \mathrm{C}: 2019: 16$ [19]-[26].

${ }^{48}$ Art 5(3)(c) covers "reproduction by the press, communication to the public or making available of published articles on current economic, political or religious topics or of broadcast works or other subjectmatter of the same character, in cases where such use is not expressly reserved, and as long as the source, including the author's name, is indicated, or use of works or other subject-matter in connection with the reporting of current events, to the extent justified by the informatory purpose and as long as the source, including the author's name, is indicated, unless this turns out to be impossible".

${ }^{49}$ EU:C:2019:16 [29]. The Advocate General interprets Art 5(3)(c) in line with the narrowly-framed art 10bis(2) of the Berne Convention. See T. Synodinou, "Mirror, mirror, tell me, is the copyright law fair and balanced? Reflections on Advocate General's conclusions on the Spiegel Online case (PartI)", Kluwer Copyright Blog, 15th February 2019.

${ }^{50}$ EU:C:2019:16 [27]-[38].
} 
The national court also referred two questions about the scope of the quotation exception. It asked, first, whether a quotation under Art 5(3)(d) could be made by hypertext link to a copy of a work, rather than through more traditional means. The Advocate General notes that the exception may apply to categories of work other than literary works (including musical, cinematographic and artistic works, for example) and that, in such circumstances, it is clearly necessary to adapt (i) the methods employed to incorporate a quotation into a quoting work and (ii) the means employed to identify quotations. ${ }^{51}$ Similarly, even in the case of a literary work, a quotation may be effected by hypertext link. However, on the facts of this case, Beck's article was published in its entirety as an independently-downloadable PDF. Links to the PDF appeared not only on the webpage carrying Spiegel Online's article about the essay, but also on its homepage. Such use of the protected work exceeds the boundaries of the quotation exception. ${ }^{52}$ While it may be possible to quote a whole work under the terms of Art 5(3)(d), ${ }^{53}$ such quotation must not enter into competition by offering a substitute for the original. ${ }^{54}$ In this instance, by offering a downloadable copy, the defendant provided a copy in potential competition with the right holder. According to the Advocate General, this conclusion concerns the limits of the exception as a general legal norm and is not therefore affected by the right holder's apparent motivation to protect his personal interests through these proceedings. ${ }^{55}$

The BGH also asked a further question about the stipulation that Art 5(3)(d) will only apply where a work has lawfully been made available to the public. The Advocate General notes that, in this instance, the work appeared to have been divulged with the consent of the author and that this issue was something which is to be determined by the national court. On Beck's own website, the essay was accompanied by a disclaimer of the views expressed in the essay and this disclaimer was not reproduced by Spiegel Online. While this might affect Beck's right to respect for his work, such moral rights do not fall with the harmonised copyright acquis. ${ }^{56}$

Finally, in his Opinion, the Advocate General turns to the referring court's questions about copyright law and the Charter. He reframes these as a single question. Do the rights of freedom of expression and of the media justify a limitation of the author's exclusive rights in a case in which a media organisation publishes a work in the context of a debate on matters of general interest ${ }^{57}$ He refers to his Opinion in Pelham, in which he notes the existence of explicit limitations and exceptions designed to reconcile the exclusive rights of authors with other fundamental rights. The legislature enjoys a margin of appreciation in determining the appropriate balance between these competing rights. The judiciary should intervene only in an exceptional case, in which the essence of a right would otherwise be violated. The emergence of judicially-created exceptions outside Art 5 would imperil the effectiveness

\footnotetext{
${ }^{51}$ Ibid. [42].

${ }^{52}$ Ibid. [44].

${ }^{53}$ Ibid. [45]. See (C-145/10) Painer EU:C:2011:239 [212]-[213].

${ }^{54}$ Ibid. [46].

${ }^{55}$ Ibid. [51].

${ }^{56}$ Ibid. [53]-[58].

${ }^{57}$ Ibid. [60].
} 
of copyright harmonisation in the Union. A form of "fair use" doctrine would be created because every use of a work, to some extent or other, implicates the right of freedom of expression. ${ }^{58}$ Under such a system, the protection accorded to the rights of authors would differ according to national courts' varying assessments of the requirements of freedom of expression and harmonisation would be transformed into a "pious wish". 59

The Advocate General acknowledges (i) that Volker Beck is a political figure, (ii) that the work at issue here expresses his opinion on a matter of general interest and (iii) that the contested publication took place in the context of a debate preceding legislative elections. However, the situation in Spiegel Online is to be distinguished from that in Funke Medien, where the copyright claim was brought by the German state, which is not itself entitled to fundamental rights protection. ${ }^{60} \mathrm{In}$ Spiegel Online, the rightholder is an individual, who enjoys a fundamental right of property. The task of balancing this right with other fundamental rights was primarily for the legislator. A political figure, such as Beck, must expect to be subject to particularly close public scrutiny and, in some circumstances, this scrutiny might justify the publication of a work without permission. Consider, for example, a situation in which misleading information about the contents of a work had been provided. ${ }^{61}$ However, here, Beck had disclosed the two versions of the essay on his own website. Spiegel Online could have achieved its objective without interfering as intrusively with his property interest, either by quoting the relevant parts of the articles or by providing a hyperlink to Beck's site. ${ }^{62}$ Spiegel Online suggested that the disclaimer on the copies of the texts published on Beck's website might prevent a reader from making an objective assessment of the material. However, in the view of the Advocate General, readers were quite capable of weighing up the value of the disclaimer. ${ }^{63}$ Similarly, he is not convinced by the argument that a hypertext link to Beck's site is insufficient for its purposes because the effectiveness of the link depends on the continued posting of the versions of the essay on that site. If the versions of the essay were to be removed from Beck's website, the balance of rights might shift. ${ }^{64}$

The Advocate General's conclusion on the balance of rights in this instance is not affected by the fact that Beck's copyright action was motivated by a desire to protect his personal interests, rather than his property interests. Copyright protects authors against the unauthorised use of works by third parties. While moral rights are not covered by the legislative acquis, the existence of such rights in national law is to be taken into account when interpreting the Directive. In this instance, if the Court were

\footnotetext{
${ }^{58}$ For a less critical view of this possibility, see C. Geiger [4].

${ }^{59}$ Ibid. [63]. The expression is drawn from A. Lucas \& J. Ginsburg [1]. The reasoning in this section is also in line with that of Lucas \& Ginsburg who write that: “... [A] trend is emerging in favour of an external limit drawn from article 10 of the European Convention on Human Rights, implying the application of a "proportionality test", which could lead to a sort of European fair use." (at 6).

${ }^{60}$ Ibid. [69].

${ }^{61}$ Ibid. [71].

${ }^{62}$ Ibid. [72].

${ }^{63}$ Ibid. [73].

${ }^{64}$ Ibid. [74].
} 
to permit the free use of works where an author is motivated by purely personal, rather than economic, considerations, the existence of moral rights in national law would not be sufficiently acknowledged. ${ }^{65}$ Furthermore, in balancing fundamental rights in a case like this, it is important to note that the right of property is not the only relevant right enjoyed by an author. Beck was motivated here by a desire to ensure that the publication of his essay was accompanied by a disclaimer of the views expressed therein. Freedom of thought, including the freedom to change beliefs, is protected under Art 10 of the Charter. ${ }^{66}$ According to the Advocate General, there is no reason why a politician, such as Beck, should not enjoy this right. How could Beck exercise his freedom to change conviction if copies of the earlier essay were freely published in his name without the disclaimer? Where Beck seeks to protect his rights under the Charter by exercising the copyright in his works within the bounds of the law, there is no abuse and any limitation on Spiegel Online's freedom of expression is justified.

\section{Analysis}

Advocate General Szpunar's analysis of the relationship between the Charter and the copyright acquis in these Opinions is important. The potentially radical consequences of the constitutional turn in European copyright law are at their most apparent in Funke Medien. In that case, the detailed structure of analysis established under the European Convention on Human Rights is applied to determine whether a government is entitled to rely on copyright law to suppress the publication of its internal documents. This is not an issue that is covered explicitly in the legislative acquis relating to copyright. Under the approach adopted by the Advocate General, the generally applicable copyright rules are effectively suspended. Any use of a work is, to some extent, covered by a user's right of freedom of expression and, in the case of a government claimant, there is no right of property to put on the other side of the "fair balance". Thus, a governmental claimant would appear to be unable to bring copyright proceedings unless a distinct "legitimate interest" in European fundamental rights law (for example, the general interest or the rights of a third party) is served in bringing the claim. Furthermore, any such claim would have to be proportionate. Presumably, this principle would also apply to many public bodies other than governments, as they would also be precluded from bringing a claim for violation of fundamental rights under the ECHR or the Charter. If this approach is followed by the Court, it would have potentially far-reaching consequences for copyright claims brought by public bodies.

Funke Medien, then, is perhaps the most dramatic of the three Opinions. However, in all three, significant proposals for the development of an analytical framework tak-

\footnotetext{
${ }^{65}$ Ibid. [77].

${ }^{66}$ Ibid. [79]. Art 10(1), which corresponds to Art 9, ECHR, provides that: "Everyone has the right to freedom of thought, conscience and religion. This right includes freedom to change religion or belief and freedom, either alone or in community with others and in public or in private, to manifest religion or belief, in worship, teaching, practice and observance".
} 
ing the Charter into account are advanced. ${ }^{67}$ As noted above, he acknowledges that any use of a copyright work by an individual is, to some extent or other, supported by the right of freedom of expression under the Charter ${ }^{68}$ and that, accordingly, any interference with a user's freedom must be capable of justification within the framework provided by the Charter. The fact that, in some instances, the balance between competing rights will inevitably come down in favour of the user, means that some of the ostensibly optional exceptions in the list set out in Art 5 of the Directive are actually mandatory. ${ }^{69}$ This seems likely to be the case for the quotation, parody and reporting current events exceptions. Furthermore, the Advocate General acknowledges that it is a necessary consequence of the Charter's supremacy that, in extremis, courts may be required to allow uses of copyright works which are not explicitly permitted under the legislative acquis. Funke Medien is presumably such a case.

However, at the same time, the Opinions in Pelham and Spiegel Online are strongly marked by concern about the potentially destabilising impact of fundamental rightsbased reasoning in copyright law. If the three Opinions are read in sequence, the latter two might be viewed as a slightly horrified response to a full realisation of the potential consequences of the structure of reasoning employed in Funke Medien. ${ }^{70}$ In Pelham and Spiegel Online, there is a marked concern to ensure that the application of the Charter by national courts does not threaten the effectiveness of copyright harmonisation. This concern is reflected in the Advocate General's underlining of the fact that primary responsibility for ensuring a fair balance between the competing rights of right holders and users rests with the legislature and that, in striking this balance, the legislature enjoys a wide margin of appreciation. Taken to its logical conclusion, the approach adopted in Funke Medien might appear to require a Charterdirected analysis in every copyright case. The strong emphasis placed on legislative discretion in the Pelham and Spiegel Online Opinions is presumably intended to temper the potentially radical consequences of the earlier Opinion. Concern to ensure that reliance on the Charter does not disrupt the normative foundations of the copyright acquis too significantly may also explain the strong assertions in Pelham and Spiegel Online that courts should only intervene to permit the use of a copyright work beyond the uses permitted under Art 5 where the "essence" of the right to freedom of expression is affected.

Over the three Opinions, the Advocate General strives to establish an interpretative methodology that acknowledges the requirement to develop copyright law compatibly with the Charter but, at the same time, both ensures that the legislative structure of European copyright law is retained intact and preserves the Court's dominance of the acquis. His analytical framework gives rise to a number of questions. For example,

\footnotetext{
${ }^{67}$ The Advocate General also interestingly identifies a further fundamental right of potential relevance in copyright proceedings. In Spiegel Online, Art 10 of the Charter, protecting freedom of belief, also weighs on the author's side of the balance. See EU:C:2019:16 [79].

${ }^{68}$ See, EU:C:2019:16 [63].

${ }^{69}$ See, for example, EU:C:2018:1002 [77]. For an argument to this effect, see J. Griffiths [8].

${ }^{70}$ The Opinion in Funke Medien has been described as "a very important and welcome step towards full taking into account of fundamental rights". See C. Geiger \& E. Izyumenko [3], 136. For an argument that there is inconsistency between the Opinions and that Pelham and Spiegel Online are less coherently reasoned than Funke Medien, see D. Jongsma [6].
} 
what is the extent and jurisprudential source of the judicial deference advocated here? Why should freedom of expression only prevail where the "essence" of the right is affected? If the fair balance of interests comes down on the side of the user's freedom of expression ought that not to be sufficient? What are the more general consequences of interpreting a copyright owner's right of property in line with copyright's supposed purposes (as suggested in Funke Medien)?

There will be many opportunities for courts and commentators to engage with these issues in future, regardless of the conclusion reached by the Court. However, in this analysis, there is opportunity only to raise one important concern about the Opinions in Pelham and Spiegel Online. As has been seen above, the Advocate General wrestles with the "structural" relationship between copyright law and the Charter. Under his approach, the interpretation of the legislative provisions of the acquis has paramount significance. However, when interpreting rights and limitations in Pelham and Spiegel Online, he does not explicitly take any account of the rights protected under the Charter at all. He comes to a number of contentious and restrictive conclusions on the scope of the right of reproduction in the case of sound recordings ${ }^{71}$ and on the boundaries of the exceptions for reporting current events and for quotation However, his conclusions on these questions are not guided by reference to the Charter or to the fundamental rights jurisprudence of the Court or of the Strasbourg Court. This is unusual in its own right, given that the relationship between the Charter and the copyright acquis is a key focus of the Opinions. It is also unusual because the Court of Justice has itself often considered the impact of the Charter in interpreting the provisions of the secondary legislation relating to copyright and related rights. ${ }^{72}$

Closer reference to the detailed content of the right of freedom of expression might have led the Advocate General to take a different approach to the interpretation of the acquis. For example, in Spiegel Online, it is suggested that the news reporting exception ought not to apply where the consumer of a report is intended to read through the referenced work in its entirety. This conclusion seems to play little regard to the public's interest in informing itself on matters of public significance, an interest considered to be of paramount significance under Art 11 of the Charter and Art 10, ECHR. In Pelham, as has been explained above, the Advocate General suggests a number of implied constraints on the concept of quotation (the need for dialogue, for the quotation to remain unchanged and for clear demarcation of the quotation). ${ }^{73}$ These constraints are imposed by reference to the apparently undisputed meaning of the terms employed in Art 5(3)(d) and are discerned without detailed analysis, even though they do not necessarily accord with cultural practice in a range of different arts and media. ${ }^{74}$ It is noteworthy that the outcome in Pelham differs from that reached by the German Constitutional Court. ${ }^{75}$ Similarly, it is not immediately apparent that a

\footnotetext{
${ }^{71}$ For criticism of this aspect of the Pelham Opinion, see L. Bently et al. [10], XXX, XXX-XXX; D. Jongsma [6].

${ }^{72}$ See n. 1 above.

${ }^{73}$ Somewhat surprisingly, in interpreting the scope of Art 5(3)(d), the Advocate General does not take the concept of "fair practice" into account.

${ }^{74}$ See L. Bently \& T. Aplin [9]; cf. B.J. Jütte \& H. Maier [2], 792.

${ }^{75}$ See EU:C:2018:1002 [15].
} 
political figure should be entitled to control the circulation of a previously published document on a matter of significant public interest, as would be the case if the Court were to follow its Advocate General in Spiegel Online. Fundamental rights are of little significance if their application does not ensure an appropriate outcome on the facts of a particular dispute. ${ }^{76}$

Over the last twenty to thirty years, huge progress has been made in European copyright harmonisation and, in the last decade, the Court has led the way. However, the process is still a relatively recent one and it seems wise to proceed with patience. The desire to flesh out the skeletal set of rules provided by the copyright acquis is understandable, but the short history of the Court's copyright jurisprudence on exceptions and limitations already demonstrates the danger of premature adoption of an inflexible principle of interpretation. ${ }^{77}$ Some divergence between national systems may be a small price to pay to avoid offering too many hostages to fortune.

Publisher's Note Springer Nature remains neutral with regard to jurisdictional claims in published maps and institutional affiliations.

Open Access This article is distributed under the terms of the Creative Commons Attribution 4.0 International License (http://creativecommons.org/licenses/by/4.0/), which permits unrestricted use, distribution, and reproduction in any medium, provided you give appropriate credit to the original author(s) and the source, provide a link to the Creative Commons license, and indicate if changes were made.

\section{References}

1. Lucas, A., Ginsburg, J.: Droit d'auteur, liberté d'expression et libre accès à l'information (étude comparée de droit Américain et Européen). Revue internationale du droit d'auteur, 4 (2016)

2. Jütte, B.J., Maier, H.: A human right to sample-will the CJEU dance to the BGH-beat? J. Intellect. Prop. Law Pract. 12, 784 (2017)

3. Geiger, C., Izyumenko, E.: Freedom of expression as an external limitation to copyright law. Eur. Intellect. Prop. Rev., 131 (2019)

4. Geiger, C.: 'Fair use' through fundamental rights in Europe: When freedom of artistic creation allows creative appropriations, CEIPI Research Paper, No. 2018-09 (CEIPI, 2018), available at https://papers.ssrn.com/sol3/papers.cfm?abstract_id=3256899

5. Geiger, C.: L'utilisation jurisprudentielle des droits fondamentaux en Europe en matière de propriété intellectuelle: Quel apport? Quelles perspectives? In: Geiger, C. (ed.) La contribution de la jurisprudence à la construction de la propriété intellectuelle en Europe, p. 193, Collection du CEIPI/Litec, Paris (2013)

6. Jongsma, D.: AG Szpunar on copyright's relation to fundamental rights: one step forward and two steps back? Available at SSRN: https://ssrn.com/abstract $=3328100$

7. Griffiths, J.: Fair dealing after Deckmyn - the United Kingdom's defence for caricature, parody \& pastiche. In: Richardson, M., Ricketson, S. (eds.) Research Handbook on Intellectual Property in Media \& Entertainment, p. 64. Edward Elgar, Cheltenham Glos (2017)

8. Griffiths, J.: Taking power tools to the acquis - the court of justice, the charter of fundamental rights and EU copyright law. In: Geiger, C. (ed.) Intellectual Property \& the Judiciary. Edward Elgar, Cheltenham Glos (2018)

9. Bently, L., Aplin, T.: Whatever became of global mandatory fair use? A case study in dysfunctional pluralism? In: Frankel, S. (ed.) Is Intellectual Property Pluralism Functional? Edward Elgar, Cheltenham Glos (2019), forthcoming

\footnotetext{
${ }^{76}$ See (C-145/10) Eva-Maria Painer v StandardVerlags GmbH EU:C:2011:798 [134].

${ }^{77}$ See (C-403/08 \& C-429/08) FA Premier League Ltd v QC Leisure EU:C:2011:631 [162]-[164].
} 
10. Bently, L., et al.: Sound Sampling, a Permitted Use Under EU Copyright Law? Opinion of the European Copyright Society in Relation to the Pending Reference before the CJEU in Case C476/17 Pelham GmbH v. Hütter. Int. Rev. Intellect. Prop. Compet. Law (2019), forthcoming. https://doi.org/10.1007/s40319-019-00798-w,

11. Husovec, M.: Intellectual property rights and integration by conflict: the past, present and future. In: Cambridge Yearbook of European Legal Studies, vol. 239 (2016)

12. Oliver, P., Stothers, C.: Intellectual property under the Charter: are the Court's scales properly calibrated? Common Mark. Law Rev. 54, 517 (2017)

13. Mylly, T.: The constitutionalisation of the European legal order: impact of human rights on intellectual property in the EU. In: Geiger, C. (ed.) Research Handbook on Human Rights and Intellectual Property, p. 103. Edward Elgar, Cheltenham Glos (2015) 